\title{
DASAR-DASAR FILSAFAT ISYRAQIYAH SUHRAWARDI
}

Miswar Abdullah

Universitas Islam Negeri Alauddin Makassar

maalmandary9@gmail.com

\begin{abstract}
Abstrak
Terdapat beberapa aliran filsafat yang muncul dalam peradaban Islam di antaranya seperti, mazhab Peripatetik atau filsafat Massya'iah dan juga mazhab Iluminasi atau filsafat Isyraqiyah. Peripatetisme Masysya' $i$ menggunakan argumentasi rasional sebagai metode filosofis, dengan tokoh-tokohnya seperti Al-farabi dan Ibnu Sina. Sementara pada Iluminisme Isyraqi selain argumentasi rasional Suhrawardi Syeikh Isyraq yang merupakan tokoh utamanya, juga sangat menekankan penjernihan ruh serta riyadhah nafsani atau latihan spiritual bagi jiwa agar manusia memahami entitas dan hakikat-hakikat riil dengan jalan penyaksian, penglihatan batin, dll. Bahkan pada metode yang disebut terakhir ini proporsinya jauh lebih besar dari pada argumentasi rasional. Implikasinya Suhrawardi lebih mengutamakan prinsipilitas mahiyah sebagai sesuatu yang ashil ketimbang wujud. Pemahaman ini kemudian berdampak pada penerimaan cahaya yang menampakkan mahiyah sebagai realitas hakiki.
\end{abstract}

Kata Kunci : Suhrawardi, Isyraqiyah, Mahiyah, Wujud, Hudhuri.

\section{A. PENDAHULUAN}

Pada satu tinjauan dapat dikatakan tema pokok pembahasan filsafat Islam tidak jauh beda dengan topik-topik yang dibahas dalam filsafat klasik, baik filsafat Yunani hingga filsafat Skolastik yang berkembang di Eropa pada abad pertengahan ${ }^{1}$ filsafat yang berkembang di barat barulah kemudian menemukan karakternya yang seperti sekarang sejak memasuki era modern, yang diawali oleh renaisans. ${ }^{2}$

${ }^{1}$ Muhammad Taqi Misbah Yazdi, Âmuzesy Falsafe, jil. 1 (cet. XII; Tehran: Syerkate Câp va Nasyre Bainalmellal, 1378 H), h. 24-37. Dalam versi Indonesia diterbitkan oleh Mizan, Muhammad Taqi Misbah Yazdi, Buku Daras Filsafat Islam (Bandung: Mizan, 2003). h. 24-40.

\footnotetext{
${ }^{2}$ Penjelasan lebih rinci silakan merujuk Muhammad Taqi Misbah Yazdi, Âmuzesy Falsafe,
} 
Oleh karena itu tidaklah mengherankan jikalau Murtadha Muthahhari mengatakan bahwa sejatinya filsafat sejak dulu salah satu jenisnya adalah yakni apa yang disebut hikmah nazari. ${ }^{3}$ Hal yang dapat dijadikan sebagai standar bagi hikmah nazari ialah yaitu pengetahuan tentang berbagai kondisi sesuatu sebagaimana "ada"nya -dan yang "akan ada" atas- sesuatu tersebut.

Hikmah nazari membicarakan berbagai "ada", karena itu masalah-masalah hikmah nazari merupakan jenis ungkapan-ungkapan khabariyah ${ }^{4}$. Ia terkait langsung dengan Ilahiyat (teologi), riadhiyat (matematika), dan thabi'iyat sehingga memiliki bidang yang sangat luas. ${ }^{5}$ Sebab penggunaan filsafat di dunia Islam secara umum ditujukan untuk seluruh ilmu-ilmu aqliyah -yang diperhadapkan dengan ilmu-ilmu naqliyah.

Lebih lanjut menurut Muthahhari terdapat dua makna filsafat bagi para filosof klasik: yaitu makna yang luas, yang secara mutlaq adalah jenis pengetahuan ma'qûl dan mencakup seluruh ilmu-ilmu ghairu naqli (non skriptural-tradisional). Dan yang lainnya adalah filsafat dalam makna khusus, yaitu ilmu Ilahiyah atau

${ }^{3}$ Jenis lainnya adalah yaitu hikmah 'amali, yakni pengetahuan tentang bagaimana perbuatan-perbuatan manusia itu baik serta cara apa yang baik dan seharusnya -bagi manusia, demikian pula sebaliknya. Hikmah 'amali merupakan pengetahuan tentang tugas-tugas dan tanggung jawab manusia dalam domain akal dan yang dapat dicapai oleh akal. Karena itu dalam hal ini mensyaratkan perbuatan-perbuatan ikhtiari. Murtada Mutahhari, Kulliyâte 'Olûme Eslami 2: Kalâm, 'Erfan, Hekmate 'Amali (cet. 35; Qom: Entesyârâte Sadrâ, 1389 H. Sy.), h.164.

${ }^{4}$ Dalam ilmu mantiq ungkapan khabariah tidak lain dari dan disebut juga qadhiyah atau proposisi, yaitu kalimat sempurna yang dapat disifati benar ataukah bohong. Ali Syirvâni, Âsynâyi bâ Elme Manteq (cet. VIII; Qom: Mo’assese-e Entesyârâte dârol'elm), h. 54.

${ }^{5}$ Murtada Mutahhari, Kulliyâte 'Olûme Eslami 2: Kalâm, 'Erfan, Hekmate 'Amali, h.163165. 
filsafat owlâ yang merupakan salah satu dari triadik hikmah atau falsafah nazhari. Itulah filsafat haqiqi atau filsafat owlâ dan atau ilmu a'lâ, filsafat 'olyâ, dan kadang juga disebut mâba'daththabî' ah atau metafisika. ${ }^{6}$

Pemikiran filsafat tidak lain sebagai pengenalan akan "ada". Para sejarawan filsafat mengatakan kumpulan karya Aristoteles membahas tentang hukum-hukum universal wujud yang ditempatkan setelah pembahasan thabi'iyat, karena itulah dinamakan mâba'daththabî'ah. Akan tetapi kemudian ahli-ahli hukama' Islam memasukkan Ilahiyat pada bagian hukum-hukum universal wujud. Karena itu Ibnu Sina mengatakan topik permasalahan filsafat yaitu almajûd bimâ huwa maujûd (maujud sebagaimana maujud tersebut). ${ }^{8}$

Namun demikian Ibnu Sina tetap saja dikenal sebagai salah seorang tokoh peripatetik atau massya'i. Jenis filsafat yang menurut Haidar Bagir tidaklah secara khusus memberikan perhatian pada aspek ontologi atau pembahasan tentang hakikat ada. Perhatian khusus pada ontologi baru benar-benar diberikan oleh aliran filsafat Islam yang lain seperti ‘irfan, Iluminisme, maupun aliran Filsafat Hikmah.

\footnotetext{
${ }^{6}$ Muthahhari menjelaskan bahwa menurut mereka di antara bagian-bagian filsafat yang beragam terdapat satu bagian yang lebih utama dibanding bagian lain. Mereka meyakini bahwa keutamaan tersebut disebabkan karena lebih burhani dan demonstrasional sehingga lebih meyakinkan ketimbang ilmu lain, selain itu seluruh pengetahuan lain membutuhkannya secara umum dan tidak sebaliknya. Murtada Mutahhari, Kolliâte Olûme Eslâmi: Manteq-Falsafe, jil. 1 (cet. XXXVI; Qom: Entesyârâte Shadrâ, 1385 H.Sy.), h. 128-130.

${ }^{7}$ Hasan Mo'allemi dkk., Târikh Falsafe eslâmi (cet. II; Qom: Markaze Bainolmellali Tarjome va Nasyre AlMostafâ, 1390 H.Sy.), h. 19.

${ }^{8}$ Hasan Mo’allemi dkk., Târikh Falsafe eslâmi . 26
} 
Iluminisme atau yang biasa juga disebut filsafat Isyraqiyah mendasarkan pemikirannya pada filsafat cahaya (nûr) yang mengidentikkan wujud dengan cahaya, sementara ketiadaan wujud dengan kegelapan. ${ }^{9}$ Untuk selanjutnya tulisan ini akan mencoba menguraikan sekelumit tentang filsafat Isyraqiyah yang didirikan oleh syeikh Isyraq Syihabuddin Suhrawardi dengan harapan sedikit dapat menambah wawasan dalam khazanah pemikiran Islam.

\section{B. LATAR BALAKANG INTELEKTUAL SUHRAWARDI}

Syihabuddin Yahya ibn Habasy ibn Amirak Abu al-Futuh Suhrawardi sangat masyhur dalam sejarah filsafat Islam sebagai guru Iluminasi (Syaikh al1syraq). ${ }^{10}$ Syahabuddin Suhrawardi lahir di desa Suhraward di Zanjan pada 549 H. ${ }^{11}$ Ia belajar pendidikan dasar yang mencakup ilmu hikmah, logika, dan prinsip-prinsip yurisprudensi pada Majduddin Al-Jili di Maraghah. Dan selanjutnya, Suhrawardi pindah ke Isfahan, yang saat itu merupakan pusat ilmiah dan intelektual paling

${ }^{9}$ Haidar Bagir, Buku Saku Filsafat Islam (cet. II; Bandung: Mizan, 2006), h. 97.

${ }^{10}$ Suhrawardi memiliki sejumlah gelar: Syaikh al-Isyraq, al-Hakim asy-Syahid, dan alMaqtul. Penyebutan al-Maqtul di belakang namanya terkait dengan proses wafatnya. Amroeni Drajat, Suhrawardi Kritik Falsafah Peripatetik (cet.I; Yogyakarta: LkiS, 2005), h. 29. Lihat juga lihat Achmad Gholib, Filsafat Islam (cet.1; Jakarta: Faza Media, 2009), h. 185.

${ }^{11}$ Mengenai kelahiran Suhrawardi yang sempat ditelusuri dari beberapa sumber, tidak ada perbedaan dalam penanggalan Hijriah dan semua menyebut angka tahun $549 \mathrm{H}$. Akan tetapi beberapa sumber tersebut berbeda dalam penyebutan angka tahun Masehi. Achmad Gholib menyebutnya pada angka 1191 M, sementara Amroeni Drajat pada tahun 1153 M, sedangkan salah satu sumber lain yang berbahasa Persia mengatakan tahun 1154 M. lihat Achmad Gholib, Filsafat Islam, h. 185, bandingkan 
penting di seluruh Iran. Suhrawardi menyelesaikan pendidikan formalnya dalam bimbingan Zahiruddin Qari. ${ }^{12}$

Setelah menyelesaikan pendidikan formalnya, Suhrawardi melakukan perjalanan ke pedalaman Iran dan bertemu banyak sesepuh Sufi. Bahkan, selama periode tersebut ia sangat terpesona dengan tasawuf dan menghabiskan waktu yang lama dalam belajar, beribadah, dan berkontemplasi. Secara berangsur perjalanannya yang terus berlanjut, makin meluas hingga sampai ke Anatolia dimana pemandangan kota dan lanskap Suriah membuatnya sangat terpesona.

Dalam salah satu perjalanan, Suhrawardi melakukan tur dari Damaskus ke Aleppo, disanalah ia bertemu Malik Zahir, putra Salahuddin Ayubi -pemimpin Muslim yang terkenal di Perang Salib. Malik Zahir yang sangat menyukai sufi dan cendekiawan begitu tertarik pada Suhrawardi yang muda lagi bijak, dan ia lalu meminta Suhrawardi untuk tinggal di istananya di Aleppo. Suhrawardi yang juga sangat menyukai pemandangan tersebut, dengan senang hati menerima tawaran Malik Zahir dan tinggal di istananya. ${ }^{13}$ Di kota Aleppo inilah ia menyelesaikan karya besarnya, yaitu, Hikmatul Isyraq.

dengan Amroeni Drajat, Suhrawardi Kritik Falsafah Peripatetik, h. 29. Dan lihat juga "Syahabuddin Suhrawardi", Wikipedia: Danesyname-e Azad. https://fa.wikipedia.org/wiki/الدين_يحيى_سهروردىشهاب، September 2019).

${ }^{12}$ Seyyed Hossein Nasr, Three Muslim Sages, terj. Ahmad Aram, Se Hakime Mosalman (Cet. V; Tehran: Sherkate Entesharate Elmi va Farhangi, 1382 H.Sy.), h. 59.

${ }^{13}$ Seyyed Hossein Nasr, Three Muslim Sages, terj. Ahmad Aram, Se Hakime Mosalman, h. 60. Bandingkan dengan Karim Mojtahedi, Sohravardi va Afkare Ou (Tehran: Pazhuheshgahe Olume 
Selama perjalanan yang banyak ia tempuh, Suhrawardi bertemu dengan banyak guru serta cendekiawan dan memperkenalkan kepada mereka Hikmatul Isyraq di beberapa halaman yang sempat ia tulis untuk mereka nilai. Untuk waktu yang terbatas, kota-kota yang termasuk ia kunjungi adalah Haran, dan tampaknya Suhrawardi telah mencapai kota Mardin yang terkenal sebelum ia berusia tiga puluh tahun, di mana ia berinteraksi dengan Fakhruddin Mardini, seorang cendekiawan dari kota bernama Manus. Kemudian mereka berdiskusi tentang masalah yang belum pernah Suhrawardi dengar sebelumnya, termasuk tradisi Mesir kuno, aqidah kepercayaan Saeb, ajaran Hermetik, perintah dan nasihat nabi yang terlupakan dan konten-konten lain yang Suhrawardi senang mendengarkannya. Disinilah Suhrawardi berbicara secara eksplisit tentang Hikmatul Isyraq. ${ }^{14}$

Namun ceramah Suhrawardi yang jujur dan langsung dalam mengekspresikan keyakinan esoteris kepada semua orang, demikian pula kecerdikan dan kecerdasannya yang membuat Suhrawardi berdebat dengan siapa pun dan memenangkannya, serta kemahirannya dalam filsafat dan tasawuf, merupakan faktor yang menyebabkan ia bermusuhan dengan banyak ulama, terutama para fuqaha. ${ }^{15}$

Ensani va Motale'ate Farhangy, 1394 H.Sy.), h. 99. Lihat juga Amroeni Drajat, Suhrawardi Kritik Falsafah Peripatetik, h. 32-33

${ }^{14}$ Karim Mojtahedi, Sohravardi va Afkare Ou, h. 64. Bandingkan dengan Amroeni Drajat, Suhrawardi Kritik Falsafah Peripatetik, h. 31, dimana Amroeni menulis:

"Suhrawardi mernperdalam kajian falsafah kepada Fakhr Ad-din Al-mardini (w. 294 H./1198 M.) yang tampaknya adalah tutor falsafah terpenting bagi Suhrawardi."

60.

\footnotetext{
${ }^{15}$ Seyyed Hossein Nasr, Three Muslim Sages, terj. Ahmad Aram, Se Hakime Mosalman, h.
} 
Akhirnya, atas dasar tuduhan bertentangan dengan akidah dan agama, ia dihukum mati oleh Malik Zahir yang terpaksa karena perintah Salahuddin Ayoubi akibat tuntutan dan tekanan para ulama. Malik Zahir pun memenjara Suhrawardi pada Rajab $587 \mathrm{H}$ dan meninggal di sana pada usia 35 , meski ada pula yang menyebut usia 36 dan $38 .{ }^{16}$

\section{FILSAFAT DAN ONTOLOGI}

Subjek filsafat adalah wujud, dan pembahasan filosofis mengenai wujud secara mutlaq. Dengan kata lain filsafat merupakan pengetahuan tentang wujud, atau teori-teori tentang wujud yang sering pula disebut ontologi. ${ }^{17}$ Karena itu, dalam filsafat Islam masalah ontologi merupakan poros utama pembasan filsafat serta bagian esensial dari bahasan-bahasannya yang disebut sebagai metafisika dalam pengertian umum, dan berbagai bahasannya mencakup seperti: konsep wujud, pembagian-pembagian wujud, hukum-hukum wujud ${ }^{18} \mathrm{dll}$.

Demikian pula pembahasan mangenai adanya perbedaan antara konsep wujud yang disandarkan pada realitas, dengan maknanya yang berkaitan dengan pikiran. Dan begitu juga bahwa terdapat perbedaan makna wujud yang dikaitkan dengan berbagai ekstensi dengan makna wujud yang dinisbahkan pada perkara-

\footnotetext{
${ }^{16}$ Amroeni Drajat, Suhrawardi Kritik Falsafah Peripatetik, h. 36-37. Bandingkan dengan Seyyed Hossein Nasr, Three Muslim Sages, terj. Ahmad Aram, Se Hakim-e Mosalman, h. 60-61.

${ }^{17}$ Moassese-e Amuzesyi va Pazuhesyie Emam Khomeyni, "Makatebe Falsafe-e Eslami”, Ma'refate Falsafi 1, h. 17.

18“Hastisyenasi Mehware Aslie Falsafe-e Eslami Ast”. Situs Resmi Khabargozarie Mehr (Mehr News Agency - MNA). http://www.mehrnews.com/news/2426866/_هنى-شناسى-محور-اصلى_فلسفهـ) (31 Agustus 2019).
} 
perkara imajinal. Konsep-konsep tersebut hanyalah beberapa contoh dari konsepkonsep yang dibahas dalam pembahasan eksistensi atau ontologi. Karena itu nampaknya topik pembahasan di dalam ontologi tidak akan keluar dari seputar masalah hubungan kausalitas, konsep teleologi, konsep ruang dan relasi ruang, waktu dan relasi waktu, dan berbagai konsep-konsep lainnya. ${ }^{19}$

Menurut Gholam Fayyazi ${ }^{20}$ masalah pertama dalam diskursus ontologi adalah mengenai eksistensi atau wujud dan ketidak-wujudan sesuatu. Setelah itu selanjutnya adalah persoalan; jika sesuatu itu ada, apakah sesuatu tersebut hanya terbatas pada perkara empirikal-inderawi dan material ataukah sesuatu yang non empiris dan non material juga ada? Jika jawaban atas masalah-masalah ini positif, maka persoalan selanjutnya adalah masalah hubungan dan atau ketiadaan hubungan di antara wujud-wujud tersebut yang disebut dengan hubungan sebab-akibat. Setelah membuktikan hubungan sebab-akibat, akhirnya rangkaian pembahasan hubungan kausalitas ini berujung pada sesuatu yang disebut "Tuhan", yang membicarakan sebab dari segala sebab dan pencipta seluruh makhluk semesta raya.

Setelah semua itu, muncullah pembahasan tentang sifat-sifat wajib dan mumkin, dan kemudian pembicaraan tentang tsabit (tetap) dan berubah (mutaghayyur) beserta karakteristiknya. Dan secara berturut-turut masuk pada diskusi

\footnotetext{
19“Ma'na-e Hasti Syenasi”, Blog Hastisyenasi: Kavesyi dar Mabahese Vojudsyenasi. http://hastishenasi.blogfa.com/post-4.aspx (31 Agustus 2019).

${ }^{20}$ Gholam Reza Fayyazi, pengajar level tertingi fiqh, ilmu ushul, tafsir, dan filsafat di Hauzah Ilmiah (seminary) Qom, beliau juga anggota dewan Jami'ah Modarresin Hauzah Ilmiah Qom, dan anggota dewan direktur Muassese-e Amuzesyi va Pazuhesyie Emam Khomeyni (Imam Khomeyni Institut; Pendidikan dan Penelitian). "Gholam Reza Fayyazi", Wikipedia: Daneshname-e Azad. https://fa.wikipedia.org/wiki/غلامرضا_فياضى (1 September 2019).
} 
mengenai maujud potensi, huduts dan qadim, dan akhirnya tersusunlah sebuah bangunan dan sistem filsafat yang berbentuk sebagaimana yang ada dalam filsafat Islam. Dengan demikian topik yang dibicarakan filsafat adalah wujud, sementara pada wujud memiliki dua jenis karakteristik: absolut (muthlaq) dan divisible, dimana pada wujud divisible ia membicarakan pembagian dan karakteristik macam-macam wujud. Lebih lanjut Fayyazi menegaskan bahwa filsafat sesungguhnya benar-benar menunjukkan sebuah pandangan dunia kepada manusia. ${ }^{21}$

\section{PEMIKIRAN FILSAFAT SUHRAWARDI}

\section{Dasar-dasar Filsafat Isyraqiyah}

Pada suatu forum ilmiah Gholam Fayyazi menegaskan bahwa filsafat (Islam) merupakan ilmu aqli yang metode analisisnya adalah metode burhani atau lebih dikenal sebagai metode demonstrasional. Sehingga dalam setiap permasalahan filsafat, tidak ada cara lain kecuali dengan argumentasi rasional sebagai jalan penyelesaian dan melakukan pembuktian. ${ }^{22}$

Secara teoritis terdapat aliran-aliran filsafat yang muncul dalam peradaban Islam seperti, mazhab Peripatetik atau filsafat Massya 'iah dan mazhab Iluminasi atau filsafat Isyraqiyah. Nampaknya kemunculan aliran-aliran tersebut disebabkan oleh

\footnotetext{
${ }^{21}$ Moassese-e Amuzesyi va Pazuhesyie Emam Khomeyni, “Makatebe Falsafe-e Eslami”, Ma'refate Falsafi 1, h. 17.

${ }^{22}$ Forum tersebut adalah suatu konfrensi studi filsafat yang menghadirkan ayatullah Muhammad Taqi Misbah Yazdi, ayatullah Hasan Mamduhi, dan ustad Gholam Reza Fayyazi. Moassese-e Amuzesyi va Pazuhesyie Emam Khomeyni, "Makatebe Falsafe-e Eslami”, Ma'refate Falsafi 1, No. 04 (1383 H. Sy.), h 17.
} 
beragamnya pandangan para filsuf terkait dengan defenisi dan pengertian filsafat, yang kemudian menyebabkan perbedaan dalam prinsip dan dasar-dasar hingga menjadi landasan bagi tegaknya mazhab-mazhab tersebut. ${ }^{23}$

Walau bagaimanapun meski terdapat aliran yang beragam namun di dalam filsafat Islam tetap saja memiliki aspek identik dan musytarak yang menyamakan, yaitu pada aspek pembuktian demonstrasional serta argumentasi rasional. Namun demikian tentu terdapat pula hal-hal yang menjadi aspek perbedaan, di antaranya adalah metode yang digunakan para penganut peripatetik dalam menganalisis permasalahan, umumnya berpegang pada akal. Dengan kata lain urgensi aliran filsafat ini -aliran yang pondasinya didirikan oleh Aristoteles- terletak pada aspek analisis masalah yang dipecahkan melalui perenungan serta pertimbangan pikiran dan argumentasi pada tahapan verifikasi-pembuktian. Dua orang filsuf di antara tokohtokoh filsafat Islam yang menunjukkan hal tersebut adalah Al-Farabi dan Ibnu Sina dan dengan itulah keduanya memperluas pandangan-pandangan filsafatnya. Filsafat jenis ini lebih menekankan pada hanya percaya akan argumentasi rasional.

Pasca Ibnu Sina muncul kecenderungan lain di antara para filosof muslim meskipun hal yang demikian itu juga telah pernah muncul dalam filsafat-filsafat Yunani kuno dan para penganut platonisme. Kecenderungan yang dimaksud tidak lain adalah bahwa untuk dapat sampai pada kebenaran-kebenaran filosofis, selain dari

\footnotetext{
23“Cera Makatebe Falsafi be Vojud Amadand? Va Makatebe Falsafi-e Eslami Kodamand?" Situs Resmi Muassese-e Farhanggie Ravaqe Hekmat. http://www.islamquest.net/fa/archive/question/id22325 (31 Agustus 2019).
} 
argumentasi rasional seseorang butuh pada penjernihan ruh dan jiwa, pemurnian dan pembersihan akhlaq, serta riyadhah nafsani atau latihan spiritual bagi jiwa dan ruh sehingga manusia mampu memahami berbagai persoalan dengan jalan penyaksian, penglihatan batin, dll. Bahkan kepercayaan pada metode yang disebut terakhir ini lebih besar dari pada argumentasi rasional. Aliran dan maktab jenis ini dikenal dengan nama Filsafat Isyraqiyah, sementara filsuf yang sangat intens menjalankan dan mempertahankan kecenderungan tersebut adalah syeikh Syahabuddin Suhrawardi yang terkenal sebagai Syeikh Isyraq. ${ }^{24}$

Filsafat isyraqiyah menegaskan bahwa seorang filsuf tidak boleh merasa cukup dengan akal. Sejatinya, filsuf haruslah menggunakan penglihatan spiritual, kemampuan syuhud dan intuisi untuk menemukan entitas dan hakikat-hakikat maujud. Sebenarnya tidak ada keraguan bahwa filsafat adalah ilmu dan pengetahuan tentang berbagai hakikat dengan jalan burhan. Akan tetapi metode burhani tersebut seharusnya digunakan setelah kemampuan syuhud telah didapatkan. Dengan kata lain, berbagai persoalan dapat di jelaskan melalui syuhud dan jika ia bukan ahli syuhud maka hakikat-hakikat tersebut tak akan dapat dipahami sama sekali.

Dalam pandangan filsafat Isyraqiyah, berdasarkan penyaksian-penyaksian syuhudiah itulah seorang penganut Isyraqiyah membangun argumentasi burhani. Menurut filsafat isyraqiyah pada hakikatnya manusia memiliki sebuah akal simplesederhana (basith) serta sebuah akal yang teriluminasi cahaya syuhud; walaupun

\footnotetext{
${ }^{24}$ Moassese-e Amuzesyi va Pazuhesyie Emam Khomeyni, "Makatebe Falsafe-e Eslami", Ma'refate falsafi 1, h. 12-17.
} 
manusia berargumentasi rasional, namun argumentasi rasional dalam pelaksanaannya tentunya melalui akal, sedangkan akal tersebut teriluminasi dengan cahaya syuhud; yakni individu yang berakal tersebut hingga pada suatu tingkatan tertentu harus melewati serangkaian tingkatan syuhud dan penyaksian spiritual akan entitas dan hakikat-hakikat riil serta segala sesuatu yang disaksikan dan diperoleh melalui syuhud dari semesta eksistensi. ${ }^{25}$

\section{Perbedaan Wujud dan Mahiyah}

Ketika berhadapan dengan benda-benda eksternal, ada dua konsep yang didapatkan dari benda-benda tersebut: pertama, konsep wujud (ada) dan kedua, konsep keapaan (mahiyah). Konsep yang pertama, berdasarkan pada prinsip univocal atau identikal makna (musytarak makna) adalah konsep wujud, maka dalam pengertian ini wujud adalah sama dalam segala hal dan berlaku (dalam satu pemaknaan) untuk semua benda eksternal. Sedangkan konsep-konsep mahiyah adalah konsep yang masing-masing mengkhusus pada objek tertentu, dan itu tidak berlaku satu sama lain bagi semua benda, sebab satu benda seperti tanah dan benda lain adalah air dan ada juga golongan manusia (jadi semuanya berbeda-beda). ${ }^{26}$ Dengan demikian, dari satu benda riil yang simpel, ada dua konsep berbeda yang didapatkan.

\footnotetext{
${ }^{25}$ Moassese-e Amuzesyi va Pazuhesyie Emam Khomeyni, "Makatebe Falsafe-e Eslami", Ma'refate Falsafi 1, h. 18.

${ }^{26}$ Ali Syirvani, Syarhe Mostalahate Falsafie Bedayatol-Hekmah va Nehayatol-Hekmah (Qom: Bostan Ketab, 1391 H. Sy.), h. 143-144.
} 
Yang satu umumnya berposisi sebagai subjek yaitu konsep mahiyah, dan yang lainnya terletak pada posisi predikat yakni konsep wujud (dalam proposisi). ${ }^{27}$

Berdasarkan penjelasan para filsuf; dari sebuah benda eksternal atau satu entitas didapatkan pahaman mahiyah, dan wujud. ${ }^{28}$ Namun sebuah pertanyaan yang muncul adalah manakah dari dua konsep tersebut yang secara intrinsik dan tanpa medium filosofis apapun, yang benar-benar mencerminkan kenyataan objektif. Yakni, setelah diterima bahwa realitas objektif itu tercermin dalam pikiran dalam bentuk proposisi simpel -subjeknya adalah konsep mahiyah dan predikatnya adalah konsep wujud, dimana keduanya dapat dinisbahkan pada realitas objektif- maka dapat dikatakan, misalnya; "sosok eksternal ini adalah manusia", sebagaimana dapat pula dikatakan "sosok ini adalah maujud (sesuatu yang berwujud)", dan tidak ada sama sekali dari dua ungkapan tesebut yang bermakna majazi-konotatif baik secara pemahaman awam maupun tata bahasa. Maka dari itu pada saat yang sama sudut pandang filsafat memunculkan pertanyaan ini -mengingat ke-satu-an dan simpelnya realitas obyektif sementara ke-multi-an konsep dengan berbagai karakternya dari konseptualisasi pikiran- apakah konsep mahiyah itulah yang dianggap sebagai realitas objektif, sementara konsep wujud adalah predikatnya sehingga cenderung dianggap sebagai aspek sekunder dan tidak prinsipil. Ataukah realitas objektif tidak

\footnotetext{
${ }^{27}$ Mohammad Taqi Mesbah Yazdi, Amuzesye Falsafe, jil. 1 (cet. XII; Sazmane Tablighate Eslami, 1378 H. Sy.), h. 292.

${ }^{28}$ Mortaza Motahhari, Majmue-e Asare Syahid Motahhari 6: Osule Falsafe va Ravesye Rialism (cet. XVIII; Tehran: Sadra, 1395 H. Sy.), h. 863.
} 
lain adalah hal yang digambarkan oleh konsep wujud, sementara konsep mahiyah hanyalah refleksi pikiran dari batas-batas pembentuk kenyataan dan realitas objektif. $^{29}$

Sebagai contoh; ketika manusia memikirkan berbagai kenyataan misalnya berpikir tentang bintang, "bahwa bintang itu ada" maka konsep dan gambaran bintang mendapat predikasi ada atau wujud. Sekalipun seluruh keynataan di alam semesta ini di tempatkan sebagai subjek, namun wujud dan "ada" tetap dapat dijadikan predikatnya. Maka sejatinya wujud dan mahiyah ini berlaku pada seluruh konsepkonsep semesta raya, akan tetapi tiada keraguan secara konseptual keduanya adalah berbeda meskipun dalam realitas eksternal keduanya menyatu pada kenyataan segala sesuatu yang berbeda-beda. Oleh karena itu konsep wujud bukanlah dan berbeda dengan konsep mahiyah, sebab jika wujud dan mahiyah itu identik maka dengan berpikir dan membayangkan sesuatu akan sama saja dengan membuktikan dan menegaskan keberadaannya; padahal dalam banyak perkara jelas tidaklah demikian. ${ }^{30}$

\section{Prinsipilitas Mahiyah}

Syeikh Ishraq, sebagaimana ibnu Sina menekankan perbedaan antara wujud dan mahiyah, dan menisbahkan kepada kaum masysya'-peripatetis yaitu pendapat mengenai bahwa predikasi internal dan eksternal wujud ke mahiyah. Sementara ia

\footnotetext{
${ }^{29}$ Mohammad Taqi Mesbah Yazdi, Amuzesye Falsafe, h. 319.

${ }^{30}$ Hasan Zarrin, "Sualat va Pasokhname-e Falsafe Pisy az Danesygah", Blog Danesy Amuzan dar Ertebat ba Ma'arefe Eslami. http://maarefemaku.mihanblog.com/extrapage/46
} 
sendiri menolak sedemikian rupa predikasi eksternal wujud atas mahiyah yaitu penolakan keutamaan wujud.

Suhrawardi menganggap bahwa wujud adalah konsep reflektif dan pemahaman sekunder, dan juga menganggap mahiyah sebagai identitas objek, serta tidak membedakan antara identitas objek dengan wujud objek di dunia eksternal. Dengan kata lain di alam eksternal, wujud dan mahiyah bukanlah dua hal yang terpisah, dan seolah baginya objektivitas mahiyah sudah pasti. Berdasarkan hal dan penjelasan ini, tidak ada lagi tempat bagi objektivitas wujud. Karena itu, Syeikh Isyraq percaya bahwa jika wujud adalah ashil dan prinsipil pada berbagai objek, maka wujud harus maujud atau berpredikat ada, dan setiap maujud pun memiliki wujud, dan hal ini tentulah daur atau pun tasalsul yang tertolak pikiran. ${ }^{31}$

Dengan demikian ia menyimpulkan bahwa mahiyah adalah ashil. Untuk membuktikannya, pertama ia membagi sifat-sifat dan hukum-hukum mahiyah menjadi dua kategori, ${ }^{32}$ yaitu; 1. sifat-sifat eksternal yang juga tergambar dalam pikiran (Seperti melek dan buta huruf, dsb); 2. Sifat-sifat yang tidak ada selain dalam pikiran (internal) dan keberadaan internalnya yang berposisi sebagai wujud eksternal (level keberadaan dan eksternalitasnya tidak lain adalah sifat subjektifnya; seperti, sifat mumkin, wujud, dll.). Pada kategori pertama, wujud internal sesuai dengan

\footnotetext{
${ }^{31}$ Mohammad Maleki, “Esyraqati az Hekmate Esyraq”, Portal Nasyriate Daftare Tablighate Eslami Hauze-e Elmie-e Qom. http://daftarmags.ir/Journal/Text/NaghdoNazar/Article/index.aspx?ArticleNumber=19538 (2 September 2019).

32"E'tebariat", Wiki Feqh: Danesyname-e Feqh va Osul va Olume Hauzavi. http://wikifeqh.ir/عتباريّاتاعfoot-main5 (2 September 2019).
} 
objek-objek eksternal, tetapi kategori kedua kesesuaian dengan objek eksternal tidak bermakna. Karena pada kategori ini konsep tersebut hanya ada di pikiran dan tidak di luar pikiran. Jadi menurut Syeikh Isyraq konsep-konsep sekunder filosofis seperti wujud, mumkin, dan wahdat, semuanya adalah konsep refleksif dan merupakan kelompok konsep-konsep sekunder logis $;{ }^{33}$ sehingga syekh Ishraq tidak membedakan antara konsep-konsep sekunder-filosofis dengan konsep-konsep sekunder muthlaq.

Menurut satu istilah, seluruh konsep-konsep sekunder baik yang filosofis maupun logis semuanya adalah refleksif. Semua pengertian ini, banyak diungkapkan oleh Syeikh Isyraq dan dalam berbagai kitabnya tentang "refleksifitas akal". ${ }^{34}$ Oleh karena itu Menurut Suhrawardi konsep atau gambaran-gambaran pikiran terdapat dua kategori: konsep objektif dan konsep subyektif. Konsep-konsep objektif selain ada di alam eksternal juga tergambarkan oleh akal, seperti hitam, putih, dan gerak, dll; sedangkan konsep subjektif adalah tidak punya wujud di alam eksternal, kecuali wujud dalam pikiran dan selain internal pikiran tidak punya wujud sama sekali. ${ }^{35}$

Asal mula keyakinan pada prinsip realitas objektif tidak lain adalah ilmu huduri terhadap realitas wijdani. ${ }^{36}$ Suhrawardi menggunakan istilah zuhur terkait

\footnotetext{
${ }^{33}$ Syahabuddin Yahya Suhrawardi, Majmoe-e Mosannefate Syeikh Esyraq, jil. 1, ed. Seyyed Hossein Nasr dkk (cet. II; Tehran: Vezarate Farhang va Amuzesye Ali, Moassese Metaleat va Tahqiqate Farhang, 1327 H. Sy.), h. 343-360. Lihat juga pada jil. 2, h. 64-74.

${ }^{34}$ Mohammad Taqi Mesbah Yazdi, Amuzesye Falsafe, h. 195.

${ }^{35}$ Syahabuddin Yahya Suhrawardi, Hekmatul-Isyraq, terj. Seyyed Ja'far Sajjadi, Hekme Alisyraq (cet. II; Tehran: Entesyarate Danesygahe Tehran, 1362 H. Sy.), h. 63, 71.

${ }^{36}$ Mohammad Taqi Mesbah Yazdi, Amuzesye Falsafe, h. 287.
} 
dengan ilmu huduri nafs pada dirinya. Ia mengatakan bahwa manusia tidaklah lalai pada dirinya sendiri, akan tetapi zahir bagi dirinya sendiri. Bahkan zat diri manusia tidak lain adalah objek zuhurnya sendiri. ${ }^{37}$ Oleh karena itu, asal usul kemunculan konsep zuhur adalah ilmu huduri nafs pada dirinya sendiri. sedangkan apa yang zahir dan muncul serta memunculkan berbagai maujud pada hakikat nafs atau diri adalah cahaya. $^{38}$ Itulah mengapa Syahabuddin Sohrawardi meyakini akan prinsipilitas cahaya, yakni menetapkan bentangan eksistensi berdasarkan cahaya, yaitu hakikat keberadaan adalah cahaya. ${ }^{39}$

\section{E. KESIMPULAN}

1. Suhrawardi adalah filosof yang juga menekuni dunia tasawuf, dan menguasai dua disiplin ilmu tersebut dengan sangat baik. Selain itu Syeikh Isyraq pun mempelajari berbagai kebijaksanaan dari berbagai tradisi seperti; Mesir kuno, Persia kuno, hermetis Yunani, dll. Namun ungkapan-ungkapannya yang kurang proporsional atas keyakinan-keyakinan batiniahnya, telah dimanfaatkan oleh para ulama kaku yang formalistik hingga mengantarnya pada hukuman mati, sehingga digelari pula Syeikh Maqtul.

\footnotetext{
${ }^{37}$ Syahabuddin Yahya Suhrawardi, Majmoe-e Mosannefate Syeikh Esyraq, jil. 1, h. 110, 114

${ }^{38}$ Syahabuddin Yahya Suhrawardi, Majmoe-e Mosannefate Syeikh Esyraq, jil. 1, h. 113.

${ }^{39}$ Hasan Mo'allemi dkk., Tarikh-e Falsafe-e Eslami (cet. II; Qom: Markaz-e BaynolMellali-e Tarjume va Nasyr-e Al-mostafa, 1390 H. Sy.), h. 296-297.
} 
2. Filsafat adalah ilmu aqliah yang yang membicarakan seputar wujud dan bebagai variannya. Ketika diperhadapkan dengan benda-benda eksternal, akal mendapatkan dua pemahaman yaitu wujud (ada) dan mahiyah (apa).

3. Menurut syeikh Isyraq Suhrawardi mahiyahlah yang ashil dan prinsipil sementara wujud hanyalah hasil refleksi akal yang bersifat sekunder dan tidak memiliki realitas obyektif. Hal ini bermula pada keyakinan suhrawardi pada ilmu huduri manusia atas dirinya sendiri (nafs). Implikasinya adalah manusia sesungguhnya zahir pada zat dirinya sementara apa yang zuhur dan muncul serta memunculkan bagi hakikat diri manusia tidak lain adalah cahaya. 


\section{DAFTAR PUSTAKA}

Bagir, Haidar. Buku Saku Filsafat Islam. cet. II; Bandung: Mizan, 2006.

"Cera Makatebe Falsafi be Vojud Amadand? Va Makatebe Falsafie Eslami Kodamand?" Situs Resmi Muassese-e Farhanggie Ravaqe Hekmat. http://www.islamquest.net/fa/archive/question/id22325 (31 Agustus 2019).

Drajat, Amroeni. Suhrawardi Kritik Falsafah Peripatetik. Cet.I; Yogyakarta: LkiS, 2005.

"E'tebariat", Wiki Feqh: Danesyname-e Feqh va Osul va Olume Hauzavi. http://wikifeqh.ir/عنباريّات|\#foot-main5 (2 September 2019).

"Gholam Reza Fayyazi", Wikipedia: Daneshname-e Azad. https://fa.wikipedia.org/wiki/غلامرضـ_فياضى (1 September 2019).

Gholib, Achmad. Filsafat Islam. Cet.1; Jakarta: Faza Media, 2009.

"Hastisyenasi Mehware Aslie Falsafe-e Eslami Ast”. Situs Resmi Khabargozarie Mehr (Mehr News Agency - MNA).

http://www.mehrnews.com/news/2426866/هنى_شناسى_محور -اصلى_فلسفه

(31 Agustus 2019).

Maleki, Mohammad. "Esyraqati az Hekmate Esyraq", Portal Nasyriate Daftare Tablighate Eslami Hauze-e Elmie-e Qom.

http://daftarmags.ir/Journal/Text/NaghdoNazar/Article/index.aspx?ArticleN umber=19538 (2 September 2019).

“Makateb Falsafe-e Eslami”, Ma'refat-e Falsafi 1, No. 04 (1383 H. Sy.).

“Ma'na-e Hasti Syenasi”, Blog Hastisyenasi: Kavesyi dar Mabahese Vojudsyenasi. http://hastishenasi.blogfa.com/post-4.aspx (31 Agustus 2019).

Mojtahedi, Karim. Sohravardi va Afkare Ou. Tehran: Pazhuheshgahe Olume Ensani va Motale'ate Farhangy, 1394 H.Sy.

Mo'allemi, Hasan dkk. Tarikhe Falsafe-e Eslami. Cet. II; Qom: Markaze BaynolMellalie Tarjume va Nasyre Al-mostafa, 1390 H. Sy.

Motahhari, Mortaza. Kolliâte Olûme Eslâmi: Manteq-Falsafe, jil. 1. cet. XXXVI; Qom: Entesyârâte Shadrâ, 1385 H.Sy. 
Motahhari, Mortaza. Kulliyâte 'Olûme Eslâmi 2: Kalâm, 'Erfan, Hekmate 'Amali. cet. 35; Qom: Entesyârâte Sadrâ, 1389 H. Sy.

Motahhari, Mortaza. Majmue-e Asare Syahid Motahhari 6: Osule Falsafe va Ravesye Rialism. Cet. XVIII; Tehran: Sadra, 1395 H. Sy.

Nasr, Seyyed Hossein. Three Muslim Sages, terj. Ahmad Aram, Se Hakime Mosalman. Cet. V; Tehran: Sherkate Entesharate Elmi va Farhangi, 1382 H.Sy.

Suhrawardi, Syahabuddin Yahya. Hekmatul-Isyraq, terj. Seyyed Ja'far Sajjadi, Hekme Al-isyraq. Cet. II; Tehran: Entesyarate Danesygahe Tehran, 1362 H. Sy.

Suhrawardi, Syahabuddin Yahya. Majmoe-e Mosannefate Syeikh Esyraq, jil. 1 dan 2, ed. Seyyed Hossein Nasr dkk. Cet. II; Tehran: Vezarate Farhang va Amuzesye Ali, Moasses-e Metaleat va Tahqiqate Farhang, 1327 H. Sy.

"Syahabuddin Suhrawardi”, Wikipedia: Danesyname-e Azad. https://fa.wikipedia.org/wiki/الدين_يحيى_سهروردىشهاب(1 September 2019).

Syirvani, Ali, Âsynâyi bâ Elme Manteq. cet. VIII; Qom: Mo’assese-e Entesyârâte dârol'elm, 1387 H.Sy.

Syirvani, Ali. Syarhe Mostalahate Falsafie Bedayatol-Hekmah va NehayatolHekmah. Qom: Bostan Ketab, 1391 H. Sy.

Yazdi, Mohammad Taqi Mesbah. Amuzesye Falsafe, jil. 1. Cet. XII; Sazman-e Tablighat-e Eslami, 1378 H. Sy.

Yazdi, Mohammad Taqi Mesbah. Buku Daras Filsafat Islam . Bandung: Mizan, 2003.

Zarrin, Hasan. "Sualat va Pasokhname-e Falsafe Pisy az Danesygah", Blog Danesy Amuzan dar Ertebat ba Ma'aref-e Eslami. http://maarefemaku.mihanblog.com/extrapage/46 (1 September 2019). 